\title{
Traders' Broker Choice, Market Liquidity and Market Structure ${ }^{1}$
}

\author{
Sugato Chakravarty \\ Purdue University \\ West Lafayette, IN 47907 \\ $317-494-6427$ \\ Fax: 317-494-0869 \\ EMAIL: SUGATO@PURDUE.EDU \\ Asani Sarkar \\ Federal Reserve Bank of New York \\ 33 Liberty Street \\ New York, NY 10045 \\ 212-720-8943 \\ Fax: 212-720-1773 \\ EMAIL: ASANI.SARKAR@FRBNY.SPRINT.COM \\ January 1997 \\ Previous version: November 1996
}

\footnotetext{
${ }^{1}$ The views expressed in this paper are those of the authors and do not necessarily represent those of the Federal Reserve Bank of New York or of the Federal Reserve System. We alone are responsible for any errors in the paper.
} 


\title{
Traders' Broker Choice, Market Liquidity and Market Structure
}

\author{
Sugato Chakravarty \\ Purdue University \\ West Lafayette, IN 47907 \\ Asani Sarkar \\ Federal Reserve Bank of New York \\ Research Department \\ 33 Liberty Street \\ New York, NY 10045
}

\begin{abstract}
$\underline{\text { Abstract }}$
Hedgers and a risk-neutral informed trader choose between a broker who takes a position in the asset (a capital broker) and a broker who does not (a discount broker). The capital broker exploits order flow information to mimic informed trades and offset hedgers' trades, reducing informed profits and hedgers' utility. But the capital broker has a larger capacity to execute hedgers' orders, increasing market depth. In equilibrium, hedgers choose the broker with the lowest price per unit of utility while the informed trader chooses the broker with the lowest price per unit of the informed order flow. However, the chosen broker may not be the one with whom market depth and net order flow are higher.

We relate traders' broker choice to market structure and show that the capital broker benefits customers relatively more in developed securities markets---i.e, markets where there are many hedgers with low levels of risk aversion and endowment risk, where the information precision is high and the asset volatility is low. The discount broker benefits customers relatively more in volatile markets where there are few hedgers with high levels of risk aversion and endowment volatility, and where information is imprecise. We derive testable predictions from our model and successfully explain up to $70 \%$ of the daily variation in the number of discount brokers and capital brokers (or,
\end{abstract}


dual traders in futures markets). 
Broker-dealers may be classified into two broad categories: capital brokers, who risk their own capital and derive their income from proprietary trading, underwriting, block positioning, and arbitrage activities; and discounters, or discount brokers, who typically do not engage in proprietary trading. Discount brokers have become major players in the U.S. securities industry. At the same time, the ratio of trading profits to industry revenue has increased from 0.18 in 1978 to a high of 0.26 in $1992 .^{2}$

The rise of proprietary trading in the brokerage industry has caused concern among customers and securities exchanges. Large customers feel brokers can use knowledge of their orders to trade for their own account, and benefit at the expense of their customers. In fact, brokers executing for customers and those engaged in proprietary trading work on the same trading floor, and at some broker-dealer firms, sit next to each other on the trading desk. ${ }^{3}$ Interestingly, a recent rule on front running proposed by the New York Stock Exchange (NYSE) presumes that a firm's proprietary trader knows about customer orders, unless appropriate fire walls are in place. ${ }^{4}$ For their part, brokerdealer firms deny that their proprietary traders are aware of customer orders. Instead, they claim, proprietary trading benefits customers by increasing the capacity of broker-dealers to provide liquidity. ${ }^{5}$

In this paper, we study customers' trade-offs in choosing between a capital broker (who trades both for customers and her own account) and a discount broker (who trades exclusively for

\footnotetext{
${ }^{2}$ The Securities Industry Factbook, 1995. Figures relate to broker-dealers that are members of the New York Stock Exchange and doing a public business. These firms account for about $70 \%$ to $80 \%$ of revenues, capital and assets of all broker-dealers in the U.S., and are thus used as a proxy for the "total" securities industry.

${ }^{3}$ See "Money Machine," Business Week, June 10, 1991, pages 81-84.

${ }^{4}$ The Investment Dealer's Digest, July 29, 1996, page 4. The proposed NYSE rule aims to increase restrictions on proprietary trading by member firms. Specifically, NYSE has proposed widening its existing Rule 92 to allow it to consider all member firms' trades--irrespective of whether they occurred on the NYSE floor or not--when looking for evidence of front running.

5"Money Machine," Business Week, June 10, 1991, pages 81-84.
} 
customers). We focus on the capital broker's ability to exploit customer information for her own trades and her capacity to provide liquidity to customers---two issues which, from the above discussion, appear to concern customers most.

We also analyze how customers' broker choice decision depends on market structure, such as market size and asset volatility. This analysis is motivated by the observation that some exchanges encourage proprietary trading by brokers only after the market is sufficiently developed. For example, the Paris Bourse, as part of its recent modernization program, has passed new laws allowing heavily capitalised firms to trade both as brokers and for their own accounts. ${ }^{6}$ Similar laws have been enacted in Spain and in London following the Big Bang. ${ }^{7}$ By contrast, the Chicago Mercantile Exchange (CME) bans capital brokers (called dual traders in futures markets) exclusively from the most liquid futures contracts. ${ }^{8}$ Our analysis helps identify the type of market where capital brokers are likely to prove most useful to customers.

In our model, a single informed trader chooses a broker to execute her order. Initially, uninformed traders do not choose brokers--noise trades are passively allocated to the broker chosen by the informed trader. The chosen broker executes the net order flow (which may include the broker's own order) through a market maker. As in Kyle (1985), the market maker prices the asset so as to make zero expected profits conditional on the net order flow.

We assume the capital broker is larger, which is in agreement with institutional facts. For example, risk-based revenues are heavily concentrated among the largest broker-dealers because of

\footnotetext{
${ }^{6}$ See Benos and Crouhy (1995).

${ }^{7}$ See Pagano and Roell (1990).

${ }^{8}$ The CME passed Regulation 552 in June 1991, suspending dual trading in contracts with an average daily trading volume of 10,000 contracts (or more) over the previous six months.
} 
the large capital commitment required for risk-based trading (Matthews, 1994). Specifically, we assume that the capital broker can execute more noise trades than the discount broker. Later, we relax this assumption when we model noise traders as risk-averse hedgers.

Our assumption that the capital broker generates more noise trader orders may be justified as follows. Schwartz (1993) observes that many discount brokers do not have over-the-counter (OTC) trading desks, and so may have a lower capacity to generate customer orders, including uninformed orders. A theoretical rationale for the assumption comes from the argument of Grossman (1989) that a broker with good trading skills is likely to ensure higher quality executions for customers. Thus, brokers who are also traders are likely to attract more customers, especially uninformed customers for whom execution quality may be more important than for informed customers.

The capital broker's larger capacity increases market depth, and allows the informed trader to trade more. However, the capital broker exploits order flow information by mimicking or piggybacking on informed trades and offsetting noise trades, which increases (in absolute value) the price paid by the informed trader for her trades. In equilibrium, the informed trader chooses the capital broker if the cost of piggybacking is less than the benefit due to her larger relative size. Otherwise, she selects the discount broker. The chosen broker provides the highest order execution quality, as measured (in absolute value) by the expected price paid per unit of expected informed order flow.

The chosen broker, however, may not be the one with whom market depth is higher. Suppose the informed trader chooses the discount broker because the extent of piggybacking is high relative to the capital broker's size advantage. But, if the discount broker is not large enough, market depth 
may be lower than that with the capital broker. Thus, the capital broker's piggybacking may create a negative externality for the market in the following sense. The informed trader loses from piggybacking. However, if the consequent reduction in informed and uninformed trading volume is offset by the capital broker's own trading, total trading volume may not decrease, and so market depth may not fall.

In the noise trader model, our results show that noise trader losses are generally higher with the broker chosen by the informed trader. For this reason, we model uninformed traders (following Spiegel and Subrahmanyam (1992)) as risk-averse hedgers who trade to protect their endowment of risky shares. With this richer specification, the interests of uninformed and informed traders are not as starkly opposed. More important, the extension allows us to relate the relative advantages of each broker type to the structure of the market.

An additional strength of the hedger model is that we no longer require that uninformed hedger orders are larger with the capital broker. Instead, we assume that the discount broker can execute the orders of a smaller number of hedgers. Since hedgers can (and do) optimally trade more with the discount broker, hedger orders can be higher with the discount broker. At the same time, the revised assumption continues to maintain the spirit of our earlier assumption that the discount broker is smaller.

Hedgers choose the broker with whom the variability of their profits is lower. The informed trader continues to choose the broker with whom their expected profits are higher. Since expected informed profits depend positively on the standard deviation of hedger trades, the informed trader chooses the broker with whom the variablity of hedger trades is higher, after adjusting for the effect of the capital broker's piggybacking on their own trades. 
We find that, while the informed trader still chooses the broker with the highest execution quality for informed orders, hedgers may not select the broker with the lowest (absolute) price per unit of hedgers' order flow. The reason is hedgers' risk-aversion, which implies that hedgers care about the price per unit of their expected utility. This result suggests that execution cost is an incomplete measure of broker performance when the broker's customers are risk-averse. Our earlier result on the negative externality associated with broker choice is robust to the model's extension.

In the extended model, both hedgers and the informed traders may choose the capital broker even when her size advantage is small relative to the cost of piggybacking, provided the amount of hedging is sufficiently high with the capital broker. This is likely to happen in markets where there are a large number of hedgers with relatively low levels of risk-aversion and endowment risk, and where the asset volatility is low and the information precision is high--characteristics typical of developed securities markets. Such markets also exhibit participation externality ${ }^{9}$ : a hedger's trading quantity increases in the number of hedgers participating in trade. We conclude that in large, liquid markets the benefit to customers from the capital broker's trading outweighs the costs. Thus, the CME's decision to ban dual trading in liquid contracts may be misguided. ${ }^{10}$

Our model predicts the following: one, broker participation is positively related to the number of hedgers and to asset volatility (provided trading is motivated mainly by hedging ${ }^{11}$ ); and, two, increases in asset volatility (number of customer trades) encourage relatively greater participation from capital (discount) brokers. Futures exchanges are ideal arenas for testing these

\footnotetext{
${ }^{9}$ See Pagano (1989) for a discussion on models with participation externality.

${ }^{10}$ Chakravarty (1994) comes to the same conclusion, though for different reasons.

${ }^{11}$ If trading is motivated mainly by information, broker participation is negatively related to asset volatility, although it is still positively related to the number of hedgers.
} 
predictions because the participation of futures floor brokers in trading is voluntary. Also, floor brokers decide, on a daily basis, whether to function as capital brokers (dual traders) or pure brokers. Consistent with our predictions, we find that the number of futures floor brokers is positively related to the number of customer trades (a proxy for the number of hedgers) and to price volatility. These two variables explain up to $70 \%$ of the daily variation in the number of futures floor traders. The relative participation rates of dual traders and pure brokers are also consistent with our predictions.

Related papers concerning the effect of capital brokers on the market include Chakravarty (1994), Fishman and Longstaff (1992), Roell (1990), and Sarkar (1995). The consensus of these papers is that the capital broker makes informed traders worse off by mimicking informed trades, and making the adverse selection problem worse for market makers. As a result, uninformed traders are better off (or at least, no worse off). ${ }^{12}$ These models imply that, when choosing brokers, informed traders should only trade with discount brokers and uninformed traders should only trade with capital brokers (or remain indifferent). We have introduced one reason why informed traders may prefer capital brokers: higher brokerage capacity, and the consequent effect on hedgers' incentive to trade.

While the focus of Hagerty and McDonald (1995) is on market fragmentation and not on broker choice, there are similarities to our paper. They compare trading through brokers and trading through a central market place (formally similar to the discount broker in our model). Brokers cross customer orders internally and charge a bid-ask spread but do not trade. With a single broker, the broker's spread is the same as in the central market. With multiple brokers, both informed and uninformed customers pay lower spreads than in the central market. Therefore, if customers had a

\footnotetext{
${ }^{12}$ The result is a little different in Roell (1990), where the capital broker observes some uninformed traders, who are better off as a result. However, those uninformed traders who are not observed, are worse off.
} 
choice, they would elect to trade through brokers rather than through a central market or be indifferent. An important difference with our paper is that, in Hagerty and McDonald (1995), quantity is fixed while our results arise from the effect of broker choice on trading quantity.

Section I describes solutions to the noise trading model when the informed trader chooses the capital broker or the discount broker. Section II determines the effect of broker choice on market parameters (including depth). Section III extends the basic model by introducing rational hedgers. In section IV, both the informed trader and hedgers choose brokers. Broker choice is related to market depth and market structure. Section V presents an empirical analysis of floor broker participation in futures markets and section VI concludes. All proofs are in the appendix.

\section{The Noise Trader Model With Brokers}

There is a single risky asset with random value v. A continuum of noise traders submit aggregate order flow $\mathrm{u}$, where $\mathrm{u}$ is normally distributed with mean 0 and a variance to be specified below. A single informed trader receives a noisy signal $\mathrm{s}$ about the true value $\mathrm{v}$, where $\mathrm{s}=\mathrm{v}+\mathrm{e}$, and decides to trade an amount $\mathrm{x} . \mathrm{v}$ and e are independently normally distributed with mean 0 and variances $\Sigma_{\mathrm{v}}$ and $\Sigma_{\mathrm{e}}$, respectively. The informed trader can choose to trade through either a capital broker (c) or a discount broker (d). If a broker is not chosen, she exits the market. Both brokers observe $\mathrm{x}$, and so they can potentially infer the signal s. However, each broker is unaware of the true distribution of e. Specifically, brokers believe e is distributed normally with mean 0 and variance $\left(\Sigma_{\mathrm{e}}+\Sigma_{\mathrm{k}}\right)$, where $\Sigma_{\mathrm{k}}>0 .{ }^{13}$ The assumption that $\Sigma>0$ ensures that the informed trader has an informational advantage over other market participants, and trades in equilibrium. It is important to

\footnotetext{
${ }^{13}$ Kandel and Pearson (1995) use a similar assumption to model different interpretations by traders of the same information signal.
} 
note, however, that we could also have ensured exitence by having multiple informed traders, as in Sarkar (1995). We do not do so here since this adds greatly to the complexity of the model-especially in the hedger model--without adding significantly greater insight.

The brokers differ in two ways. First, a capital broker takes a position in the asset, while a discount broker does not. Second, the variance of $u$ depends upon the type of broker chosen. With a capital broker, the variance of $\mathrm{u}$ is $\Sigma_{\mathrm{u}}$ while, with a discount broker, the variance of $\mathrm{u}$ is $\alpha \Sigma_{\mathrm{u}}$ where $0<\alpha \leq 1$. The assumption that $0<\alpha \leq 1$ may be interpreted as follows. The capital broker is a larger firm able to execute more uninformed trades than the discount broker, either by spending more on marketing, or by having a larger capacity to handle retail trades (because the discount broker does not have an over-the-counter (OTC) trading desk, for example).

Figure 1 shows the sequence of decisions made by agents. The informed trader observes the signal s, chooses a broker, and submits a market order $\mathrm{x}_{\mathrm{i}}, \mathrm{i}=\mathrm{c}, \mathrm{d}$ to the chosen broker. If a capital broker is chosen, she observes $\mathrm{x}_{\mathrm{c}}$, collects noise trades $\mathrm{u}$ with variance $\Sigma_{\mathrm{u}}$ and decides an amount $\mathrm{z}$ to trade on her own account. Finally, she submits the net order flow $y_{c}$, where $y_{c}=x_{c}+u+z$, to the market maker for execution. If a discount broker is chosen, she observes $\mathrm{x}_{\mathrm{d}},{ }^{14}$ collects noise trades $\mathrm{u}$ with variance $\alpha \Sigma_{\mathrm{u}}$ and submits a net order flow $\mathrm{d}$, where $\mathrm{y} \overline{\mathrm{a}} \mathrm{x}+\mathrm{u}$, to the market maker for execution.

As in Kyle (1985), the market maker is assumed to make zero expected profits conditional on the net order flow realized. Thus, if the capital broker is chosen, the price is $\mathrm{p}_{\mathrm{c}}=\mathrm{E}\left(\mathrm{v} \mid \mathrm{y}_{\mathrm{c}}\right)$, and if the discount broker is chosen, the price is $\mathrm{p}_{\mathrm{d}}=\mathrm{E}\left(\mathrm{v} \mid \mathrm{y}_{\mathrm{d}}\right)$. We assume that the market maker knows the private information with the same precision as the brokers. In other words, the market maker

\footnotetext{
${ }^{14}$ Note that the value of $\mathrm{x}$, the informed trade, depends on the broker chosen.
} 
believes that the distribution of $\mathrm{s}$ is normal with mean 0 and variance $\Sigma_{\mathrm{s}}+\Sigma_{\mathrm{k}}$, and he makes zero expected profits when the expectation is taken with respect to his perceived distribution of s. We maintain this assumption for the remainder of this paper.

The purpose of the above assumption is to treat brokers and the market maker symmetrically, in an informational sense. All our results remain qualitatively intact if we assume that the market maker's prior on $\mathrm{s}$ is the same as that of the informed trader.

\section{A. The Solution When a Capital Broker is Chosen}

Below, we sketch the solution method, leaving details for the appendix. Given her observations of $\mathrm{x}_{\mathrm{c}}$ and $\mathrm{u}$, the capital broker chooses her trade $\mathrm{z}$ to maximize expected profits $\Pi_{\mathrm{c}}=$ $\mathrm{E}\left[\left\{\left(\mathrm{v}-\mathrm{p}_{\mathrm{c}}\right) \mathrm{z}\right\} \mid \mathrm{u}, \mathrm{x}_{\mathrm{c}}\right]$. The informed trader chooses her trade $\mathrm{x}_{\mathrm{c}}$ to maximize expected profits $\Pi_{\mathrm{I}}$, where $\Pi_{\mathrm{l}}=\mathrm{E}\left[\left\{\left(\mathrm{v}-\mathrm{p}_{\mathrm{c}}\right) \mathrm{x}_{\mathrm{c}}\right\} \mid \mathrm{s}\right]$, conditional on her information s and the capital broker's optimal trading rule $\mathrm{z}\left(\mathrm{x}_{\mathrm{c}}, \mathrm{u}\right)$. Finally, the price is $\mathrm{p}_{\mathrm{c}}=\mathrm{E}\left(\mathrm{v} \mid \mathrm{y}_{\mathrm{c}}\right)=\lambda_{\mathrm{c}} \mathrm{y}_{\mathrm{c}}$, where $\lambda_{\mathrm{c}}=\operatorname{cov}\left(\mathrm{v}, \mathrm{y}_{\mathrm{c}}\right) / \operatorname{var}\left(\mathrm{y}_{\mathrm{c}}\right)$.

Define $\mathrm{t}=\Sigma_{\sqrt{ }} / \Sigma_{\mathrm{s}}$, where $\mathrm{t}$ measures the unconditional precision of $\mathrm{s}$ and takes on values in the unit interval. Then $\mathrm{E}(\mathrm{v} \mid \mathrm{s})=\mathrm{ts}$. Lemma 1 describes the capital broker equilibrium.

Lemma 1: Suppose the informed trader chooses the capital broker. If $\Sigma_{\mathrm{s}}>\Sigma_{k}>0$, and $t>0$, there is a unique equilibrium with $x_{c}=A_{c} s, z=B x_{c}-u / 2$, and $p_{c}=\lambda_{c} y_{c}$ where:

$$
\begin{gathered}
A_{C}=\frac{\Sigma_{k}}{\Sigma_{s}+\Sigma_{k}} \sqrt{\frac{\Sigma_{u}}{\Sigma_{s}-\Sigma_{k}}} \\
B=\frac{1}{2} \frac{\Sigma_{s}-\Sigma_{k}}{\Sigma_{k}}
\end{gathered}
$$




$$
\lambda_{c}=t \sqrt{\frac{\Sigma_{s}-\Sigma_{k}}{\Sigma_{u}}}
$$

Since $\lambda_{\mathrm{c}}>0$ is necessary for a solution, we need $\Sigma_{\zeta} \Sigma_{\mathrm{k}}$ in equilibrium. This is because $\Sigma_{\mathrm{k}}$ adds to the noise in the informed order flow. As $\Sigma_{\mathrm{k}} \rightarrow \Sigma_{\mathrm{s}}$, the insider's trading intensity is very high, and it becomes unprofitable for the market maker to price the asset.

$\Sigma_{\mathrm{s}}>\Sigma_{\mathrm{k}}$ implies B $>0$--i.e., the capital broker piggybacks on informed trades. Also, B depends inversely on $\Sigma_{\mathrm{k}}$, implying that the lower the noise in the capital broker's observation of the informed order, the greater is the piggybacking. Similarly, the informed trading intensity is increasing in $\Sigma_{\mathrm{k}}$ : piggybacking hurts the informed trader, since it makes the price higher (in absolute value). In fact, the trading intensity is zero when $\Sigma_{\mathrm{k}}=0$, and there is no equilibrium. This is proposition 2 of Chakravarty (1994) and lemma 1 of Sarkar (1995).

\section{B. The Solution When a Discount Broker is Chosen}

The informed trader chooses $\mathrm{x}_{\mathrm{d}}$ to maximize her conditional expected profits $\prod=\mathrm{I}=\mathrm{E}\{\mathrm{v}$ $\left.\left.\left.\mathrm{p}_{\mathrm{d}}\right) \mathrm{x}_{\mathrm{d}}\right\} \mid \mathrm{s}\right]$. The discount broker collects noise trades with variance $\alpha \Sigma_{\mathrm{u}}$ and submits the net order flow to the market maker for execution. Lemma 2 describes the solution when the informed trader chooses the discount broker.

Lemma 2: Suppose the informed trader chooses the discount broker. If $\Sigma_{\mathrm{s}}>\Sigma_{\mathrm{k}}, \mathrm{t}>\mathbf{0}$, and $\alpha>0$, there exists a unique equilibrium in which $x_{d}=A_{d} s$, and $p_{d}=\lambda_{d} y_{d}$, where:

$$
A_{d}=\sqrt{\frac{\alpha \Sigma_{u}}{\Sigma_{s}-\Sigma_{k}}}
$$




$$
\lambda_{d}=\frac{t}{2} \sqrt{\frac{\Sigma_{s}-\Sigma_{k}}{\alpha \Sigma_{u}}}
$$

\section{Optimal Broker Choice and Market Depth in the Noise Trader Model}

\section{A. The Informed Trader's Optimal Broker Choice}

The informed trader chooses the broker that gives her higher unconditional expected profits, which is proportional to the informed trading intensity. Define $K=\Sigma_{\mathrm{k}} /\left(\Sigma_{\mathrm{s}}+\Sigma_{\mathrm{k}}\right)$. From (1) and (4), the difference in informed trading intensities between the two brokers is:

$$
A_{d}-A_{C}=\frac{\sqrt{\Sigma_{u}}}{\sqrt{\sum_{s}-\Sigma_{k}}}(\sqrt{\alpha}-K)
$$

The following proposition characterizes the informed trader's choice of a broker.

Proposition 1: The informed trader chooses the discount (capital) broker if and only if $\sqrt{ } \alpha$ is greater (less) than K. A sufficient condition for the discount broker to be chosen is that $\alpha \geq 1 / 4$.

Low values of $\mathrm{K}$ and high values of $\alpha$ favor the choice of the discount broker. $\mathrm{K}$ is an inverse measure of the capital broker's ability to infer information. If $\Sigma_{\mathrm{k}}$ is small, $\mathrm{K}$ is small, the capital broker can infer information with relative ease and so the extent of piggybacking is large. When $\alpha<1$, there are less noise trades with the discount broker, reducing market depth and informed trading intensity. When choosing a broker, the insider trades off the cost of piggybacking by the capital broker against the benefits of her larger size.

A common measure of broker performance is the quality of her order execution, which is 
inversely related to the price per unit of customer order. We would like an ex-ante measure of execution quality--i.e., one that is not dependent on the actual realization of noise trades or the information signal. Further, we want to treat purchases and sales symmetrically. Thus, we define the broker i's trader execution quality as $\mathrm{E}\left(\left|\mathrm{x}_{\mathrm{i}}\right|\right) / \mathrm{E}\left(\left|\mathrm{P}_{\mathrm{i}}\right|\right), \mathrm{i}=\mathrm{c}, \mathrm{d} .{ }^{15}$ Execution is better with broker $\mathrm{i}$ if the average price per unit of expected informed order flow is lower with broker $\mathrm{i}$.

\section{Corollary 1. The informed trader chooses the broker who obtains better execution.}

$\mathrm{E}\left(\left|\mathrm{P}_{\mathrm{i}}\right|\right)$ is proportional to the standard deviation of the price, which in turn varies inversely with (the square root of) depth and positively with the standard deviation of the order flow. Since the capital broker offsets part of the noise trade, market depth is lower with the capital broker, but so is the standard deviation of the order flow. These effects cancel out exactly, and so price variance is the same no matter which broker is chosen. Informed trades are higher with the chosen broker, and so price variance per unit of expected informed order flow is lower.

Although noise traders do not choose brokers, it is instructive to consider their losses to informed trading (including the capital broker's trading) with each broker.

\section{Corollary 2. Define $K^{\star}=K+\left[1+\left(\Sigma_{k} / \Sigma_{s}\right)\right]\left(\Sigma_{s}-\Sigma_{k}\right) /\left(\Sigma_{s}+\Sigma_{k}\right)$ and note that $K^{\star}>K$. Uninformed losses are lower with the discount (capital) broker if and only if $\sqrt{ } \alpha$ is less (greater) than $K^{\star}$.}

Not surprisingly, the interests of noise traders and the informed trader are generally opposed. When $\sqrt{ } \alpha \leq K$, the informed trader chooses the capital broker (from proposition one) whereas noise traders prefer the discount broker (from corollary two). When $\sqrt{ } \alpha \geq \mathrm{K}^{\star}$, the informed trader chooses the discount broker while noise traders prefer the capital broker. Noise traders and the informed

\footnotetext{
${ }^{15}$ An alternative measure is $\mathrm{E}\left(\left|\mathrm{x}_{\mathrm{i}}\right| /\left|\mathrm{p}_{\mathrm{i}}\right|\right)$, for $\mathrm{i}=\mathrm{c}, \mathrm{d}$. A technical problem with this measure is that the ratio inside the expectations operator is not distributed normally.
} 
trader agree only when $\sqrt{ } \alpha \in\left(\mathrm{K}, \mathrm{K}^{\star}\right)$. If noise traders choose brokers to minimize their losses, then equilibrium would exist only in the "agreement" interval $\sqrt{ } \alpha \in\left(\mathrm{K}, \mathrm{K}^{\star}\right)$. Figure 2 illustrates the above discussion. ITP, NTL, CB and DB denote informed trader profits, nose trader losses, capital broker and discount broker, respectively.

\begin{tabular}{lll} 
ITP higher with CB & $\begin{array}{l}\text { ITP higher with DB } \\
\text { NTL lower with DB }\end{array}$ & $\begin{array}{l}\text { ITP higher with DB } \\
\text { NTL lower with CB }\end{array}$ \\
\hline 0 & $\mathrm{~K}$ & $\mathrm{~K}^{\star}$
\end{tabular}

Figure 2: Noise trader losses and informed profits with brokers

\section{B. The Effect of Broker Choice on Market Depth and Price Informativeness}

Since the two brokers add to and absorb liquidity in different ways, broker choice may affect market depth and the informativeness of prices. From (3) and (5), the difference in market depth under the two brokers is:

$$
\frac{1}{\lambda_{d}}-\frac{1}{\lambda_{c}}=\frac{\sqrt{\Sigma_{u}}}{\sqrt{\Sigma_{s}-\Sigma_{k}}} t(2 \sqrt{\alpha}-1)
$$

Depth is higher with the discount (capital) broker if and only if $\sqrt{ } \alpha$ is greater (less) than $1 / 2$. The intuition behind this result is as follows. The capital broker absorbs liquidity in two ways. First, she makes it more expensive for the informed trader to trade. However, the reduction in informed order flow is exactly offset by the capital broker's own trades. Second, she also offsets half of the noisy order flow and this reduces depth by half. The net effect is that, when the capital broker is 
chosen, market depth is reduced by half. When the discount broker is chosen, she brings in less noisy order flow and this too reduces market depth by a factor of $\checkmark \alpha$.

When choosing a broker, the informed trader maximizes personal trading profits, not market depth. Proposition 2 examines whether the informed trader's private broker choice is consistent with higher market depth.

Proposition 2. (i) If $\sqrt{ } \alpha \leq \mathrm{K}$, the capital broker is chosen, and market depth is higher with the capital broker. (ii) If $\sqrt{ } \alpha>1 / 2$, the discount broker is chosen, and market depth is higher with the discount broker. (iii) If $\mathrm{K}<\sqrt{ } \alpha<1 / 2$, the discount broker is chosen but market depth is lower with the discount broker.

Figure 2 illustrates proposition 2. CB (DB) denotes capital (discount) broker, and md is market depth.

\begin{tabular}{lll}
$\begin{array}{l}\text { CB chosen; md } \\
\text { higher }\end{array}$ & $\begin{array}{l}\text { DB chosen; md } \\
\text { lower }\end{array}$ & $\begin{array}{l}\text { DB chosen; md } \\
\text { higher }\end{array}$ \\
\hline 0 & $\mathrm{~K}$ & 0.5
\end{tabular}

Figure 3: Market depth and broker choice

If the capital broker is large and does not piggyback much $(K \geq \sqrt{ } \alpha)$, or the discount broker is sufficiently large $(\sqrt{ } \alpha \geq 1 / 2)$, the informed trader chooses the broker best for market depth. However, if the capital broker piggybacks a lot $(\mathrm{K}<\sqrt{ } \alpha)$, the informed trader chooses the discount broker to avoid piggybacking. But this reduces market depth since the discount broker is relatively small $(\sqrt{ } \alpha<1 / 2)$. The informed trader's broker choice creates a negative externality for the market 
because piggybacking is a cost to the informed trader but not to the market: it reduces informed trading volume but not total trading volume.

\section{Corollary 3. Price informativeness is invariant with respect to the choice of broker.}

Price informativeness with broker $i$ is defined as $\left[\Sigma_{v}-\operatorname{var}\left(v \mid p_{i}\right)\right]$, which is the same as the variance of the price. As discussed earlier, price variance is the same with both brokers.

\section{The Hedger Model With Brokers}

As illustrated in figure 2, noise traders tend to be worse off with the broker chosen by the informed trader. In this section, we model uninformed traders as risk-averse hedgers, following Spiegel and Subrahmanyam (1992). Although hedgers face the risk of trading with informed traders, their interests are not as directly opposed to those of the informed trader. This allows us to expand the parameter space over which hedgers and the informed trader agree on their choice of brokers. The richer specification of the hedger model also allows us to relax the assumption that the capital broker has higher uninformed order flow. Finally, the hedger model enables us to relate the relative benefits of each broker type to the structure of the market.

\section{A. Equilibrium with Rational Hedgers}

There are $\mathrm{h}$ risk-averse uninformed traders who trade to "hedge" their endowments of shares

of the risky asset. Each hedger $j$ has random endowment $w_{j}$ shares of the asset. $w_{j}$ is normally distributed with mean 0 and variance $\Sigma_{\mathrm{w}}$. All random variables are independent of one another. Hedgers have negative exponential utility functions with risk-aversion parameter R.

Hedger $\mathrm{j}$ submits market order $\mathrm{u}_{\mathrm{j}, \mathrm{i}}$ to broker $\mathrm{i}=\mathrm{c}, \mathrm{d}$. Total uninformed trading volume with 
broker $\mathrm{i}$ is $\mathrm{u}_{\mathrm{i}}=\Sigma_{\mathrm{j}} \mathrm{u}_{\mathrm{j}, \mathrm{i}}$. Denote $\mathrm{H}_{\mathrm{j}, \mathrm{i}}$ as hedger $\mathrm{j}$ 's profits with the $\mathrm{i}$-th broker. Hedger $\mathrm{j}$ chooses $\mu_{\mathrm{j}, \mathrm{i}}$ to maximize her certainty equivalent profits $\mathrm{G}_{\mathrm{j}, \mathrm{i}}=\mathrm{E}\left(\mathrm{H}_{\mathrm{j}, \mathrm{i}} \mid \mathrm{w}_{\mathrm{j}}\right)-(\mathrm{R} / 2) \operatorname{var}\left(\mathrm{H}_{\mathrm{j}, \mathrm{i}} \mid \mathrm{w}_{\mathrm{j}}\right)$. We assume that, when trading with broker $\mathrm{i}$, hedger $\mathrm{j}$ follows a linear trading strategy $\mathrm{u}_{\mathrm{j}, \mathrm{i}}=\mathrm{D}_{\mathrm{i}} \mathrm{w}_{\mathrm{j}} \cdot\left|\mathrm{D}_{\mathrm{i}}\right|, \mathrm{i}=\mathrm{c}, \mathrm{d}$ denote the absolute hedging intensity with broker i. Since each $\mathrm{w}_{\mathrm{j}}$ is independent of $\mathrm{v}$, the informed trader and brokers' maximization problem remain the same as before. So, in what follows, we only describe hedgers' maximization problem.

We assume that the number of hedgers is $\mathrm{h}$ with the capital broker, and $\alpha \mathrm{h}$ with the discount broker, $0<\alpha \leq 1$ and $\alpha \mathrm{h} \geq 1 . \alpha$ may be interpreted as an index of hedger participation in the market. $0<\alpha \leq 1$ implies that the discount broker has a lower capacity to handle hedger trades, leading to lower hedger participation with the discount broker. $\alpha \mathrm{h} \geq 1$ implies that at least one hedger participates with the discount broker. ${ }^{16}$ Note that, if $\alpha\left|D_{d}\right|>\left|D_{c}\right|$, hedgers' order flow and the variance of hedger trades are higher with the discount broker---a possibility ruled out by assumption in the noise trader model.

Figure 4 describes the decision sequence of agents in the hedger model. We consider only equilibria where hedgers and the informed trader all choose the same broker. Otherwise informed and hedger trading become segregated, and no equilibrium exists. We also maintain our previous assumption that the broker not chosen exits the market. Lemma 3 characterizes the solution to the trading model when hedgers and the informed trader choose the capital broker.

Lemma 3: Suppose the informed trader and hedgers choose the capital broker. An equilibrium exists if $\Sigma_{\mathrm{s}}>\Sigma_{\mathrm{k}}>0$, and $\mathrm{N}_{1}>\mathrm{N}_{\mathfrak{z}}$ where $\mathrm{N}_{1}$ and $\mathrm{N}_{2}$ are defined in (12) and (13) below. The informed

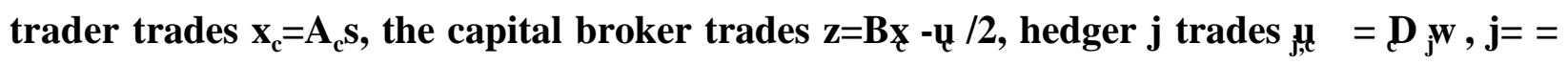
$1, \ldots, h$, where $D_{c}<0$, the market price is $p_{c}=\lambda_{c} y_{c}$ and:

\footnotetext{
${ }^{16}$ In equilibrium, when $\alpha \mathrm{h}<1$, the sufficient condition for hedgers to choose the discount broker is never satisfied.
} 


$$
A_{C}=\frac{\Sigma_{k}}{\Sigma_{s}+\Sigma_{k}}\left(-D_{C}\right) \sqrt{\frac{h \Sigma_{w}}{\Sigma_{s}-\Sigma_{k}}}
$$

$$
\begin{gathered}
B=\frac{1}{2} \frac{\Sigma_{s}-\Sigma_{k}}{\Sigma_{k}} \\
-\lambda_{C} D_{C}=t \sqrt{\frac{\Sigma_{s}-\Sigma_{k}}{h \Sigma_{w}}} \\
D_{C}=\frac{N_{2}-N_{1}}{N_{1}-w h e r e} N_{3} \\
N_{3}=R \frac{t^{2}}{2 h}\left(\Sigma_{s}-\Sigma_{k}\right) \\
N_{1}=R \Sigma_{V}(2-t) \\
N_{2}=2 t \sqrt{\frac{\Sigma_{s}-\Sigma_{k}}{h \Sigma_{w}}}
\end{gathered}
$$

As in Spiegel and Subrahmanyam (1992), for $\lambda_{c}>0$, we require $D_{c}<0$ in equilibrium. Since $\mathrm{N}_{1}>\mathrm{N}_{3}$ from definition, we need $\mathrm{N}>\mathrm{N}$, which requires that the degree of risk-aversion $\mathrm{R}$, the number of hedgers $\mathrm{h}$ and the noise variances $\Sigma_{\mathrm{w}}, \Sigma_{\mathrm{e}}$ and $\Sigma_{\mathrm{k}}$ are large. Intuitively, the amount of noise 
and risk-aversion must be large relative to information available for the market maker to price the asset.

When the discount broker is chosen, the number of hedgers is $\alpha$ h. Although equilibrium is still unique, the equilibrium outcomes are sensitive to $\alpha$. Specifically, equilibrium exists for two disjoint intervals of $\alpha$--one for relatively low values of $\alpha$, and the other for relatively high values of $\alpha$. We refer to these as the low $\alpha$ and high $\alpha$ regions, respectively. Lemma 4 describes the equilibrium when all traders choose the discount broker.

Lemma 4: Suppose hedgers and the informed trader choose the discount broker. An equilibrium exists if $\Sigma_{s}>\Sigma_{\mathrm{k}}>0, \alpha>0, t>0$, and one of the following two conditions hold:
a) $\sqrt{ } \alpha>\operatorname{Max}\left\{\mathbf{N}_{2} / \mathbf{N}_{1}, \sqrt{ } \mathbf{N}_{3} / \sqrt{ } \mathbf{N}_{1}\right\}$ or
b) $\sqrt{ } \alpha<\operatorname{Min}\left\{\mathbf{N}_{2} / \mathbf{N}_{1}, \sqrt{ } \mathbf{N}_{3} / \sqrt{ } \mathbf{N}_{1}\right\}$.

$N_{i}, i=1,2,3$, are defined in (12) - (14). The informed trader trades $x_{d}=A_{d} s$, hedger $j$ trades $u_{j, d}=$ $D_{d} w_{j}, j=1, \ldots, \alpha h$, where $D_{d}<0$, the price is $p_{d}=\lambda_{d} y_{d}$, and:

$$
\begin{gathered}
A_{d}=\left(-D_{d}\right) \sqrt{\frac{\alpha h \Sigma_{w}}{\Sigma_{s}-\Sigma_{k}}} \\
-\lambda_{d} D_{d}=\frac{t}{2} \sqrt{\frac{\Sigma_{s}-\Sigma_{k}}{\alpha h \Sigma_{w}}} \\
D_{d}=\frac{\frac{N_{2}}{\sqrt{\alpha}-N_{1}}}{N_{1}-\frac{N_{3}}{\alpha}}
\end{gathered}
$$


The high $\alpha$ equilibrium region, corresponding to condition (a) is similar (identical for $\alpha=1$ ) to the capital broker equilibrium in lemma 3, after adjusting for hedger participation (i.e., replacing $\mathrm{h}$ with $\alpha \mathrm{h}$ ). Specifically, in the equilibrium region, information is small relative to noise and riskaversion. The low $\alpha$ region, corresponding to condition (b), is unique to the discount broker equilibrium. It holds for volatile markets with few hedgers, where information is large relative to risk-aversion and noise ( $\Sigma_{\mathrm{v}}$ is large and $\mathrm{R}, \alpha \mathrm{h}, \sum_{\mathrm{w}}, \sum_{\mathrm{N}}$ and $\Sigma$ are small). Intuitively, high asset volatility induces hedgers to trade even though the risk of trading with the informed trader is high. Hedgers' participation, in turn, enables market makers to price the asset in the face of high adverse selection risk. Since $\mathrm{N}_{3} / \mathrm{N}_{1}<(1 / \mathrm{h})$ from (12) and (14), $\alpha \mathrm{h}<1$ in this equilibrium. So, from now on, we will ignore the low $\alpha$ equilibrium region corresponding to condition (b).

\section{Optimal Broker Choice, Market Depth and Market Structure in the Hedger Model}

\section{A. Broker Choice, Market Depth, the Net Order Flow and Price Informativeness}

Hedger $\mathrm{j}$ will choose the discount broker if her expected utility is greater from trading with a discount broker-- i.e., $\mathrm{E}\left(\mathrm{G}_{\mathrm{j}, \mathrm{d}}\right)>\mathrm{E}\left(\mathrm{G}_{\mathrm{j}, \mathrm{c}}\right)$. The difference in expected utilities is:

$$
\begin{aligned}
\frac{1-E\left(G_{j, c}\right)}{\Sigma_{W}} & =\lambda_{d}\left|D_{d}\right|\left(\left|D_{d}\right|-\sqrt{\alpha}\left|D_{c}\right|\right) \\
& +R \Sigma_{V}\left(1-\frac{t}{2}\right)\left(\left|D_{d}\right|-\left|D_{c}\right|\right) \\
& +\frac{R}{2} \Sigma_{V}\left(\lambda_{d} D_{d}\right)^{2}\left[\left(D_{d}\right)^{2}(\alpha h-1)-\left(D_{C}\right)^{2} \alpha(1\right. \\
& \left.+\frac{R}{2} \Sigma_{V}\left(1-\frac{3 t}{4}+\frac{t \Sigma_{k}}{4 \Sigma_{s}}\right)\left[\left(D_{d}\right)^{2}-\left(D_{C}\right)^{2}\right)\right]
\end{aligned}
$$

The informed trader will choose the discount (capital) broker if the difference in trading intensities, given below, is positive (negative): 


$$
A_{d}-A_{c}=\frac{\sqrt{h \Sigma_{w}}}{\sqrt{\Sigma_{s}-\Sigma_{k}}}\left(\sqrt{\alpha}\left|D_{d}\right|-K\left|D_{c}\right|\right)
$$

The variance of hedger trades with the discount broker is $\alpha \mathrm{h}\left(\mathrm{D}_{\mathrm{d}}\right)^{2} \Sigma_{\mathrm{w}}$ and the variance of hedger trades with the capital broker is $\mathrm{h}\left(\mathrm{D}_{\mathrm{c}}\right)^{2} \Sigma_{\mathrm{w}}$. Equation (19) says that the informed trader chooses the discount (capital) broker if and only if the standard deviation of hedger trades with the discount broker $\left(\sqrt{ } \alpha\left|D_{d}\right|\right)$ exceeds (is less than) $K\left|D_{c}\right|$, the standard deviation of hedger trades with the capital broker, adjusted for the piggybacking factor K.

We want to derive conditions such that both the informed trader and hedgers choose a particular broker. Because of the complexity of (18), simple necessary and sufficient conditions for hedgers' broker choice are difficult to derive. We therefore characterize hedgers' broker choice analytically in terms of sufficient conditions. It is shown in lemma A1 of the appendix that hedgers choose (i) the capital broker if $\sqrt{ } \alpha\left|D_{c}\right|>\left|D_{d}\right|$; and (ii) the discount broker if $[\alpha(h-1)]^{1 / 2}\left|D_{c}\right|<[\alpha h-$ $1]^{1 / 2}\left|D_{d}\right|$. Proposition 3 derives sufficient conditions for the simultaneous broker choice of the informed trader and hedgers.

Proposition 3. (a) Both hedgers and the informed trader choose the capital broker if either (i) $\alpha>K$ and $K\left|D_{c}\right|>V_{\alpha}\left|D_{d}\right| ;$ or (ii) $\alpha \leq K$ and $\sqrt{ } \alpha\left|D_{c}\right|>\left|D_{d}\right|$.

(b) If $\alpha \mathrm{h} \leq 1$, then the sufficient condition for hedgers to choose the discount broker is never satisfied. If $\alpha h>1$, and $h>1$, both hedgers and the informed trader choose the discount broker if $\alpha>K$ and $[\alpha(h-1)]^{1 / 2}\left|D_{c}\right|<[\alpha h-1]^{1 / 2}\left|D_{d}\right|$.

Recall that, in the noise trader model the informed trader chooses the discount broker when $\alpha>\mathrm{K}$ : the extent of piggybacking is high relative to $\alpha$. Here, the informed trader will choose the capital broker, even when $\alpha>\mathrm{K}$, provided the standard deviation of hedger trades, adjusted for 
piggybacking, is higher with the capital broker. This condition further ensures that hedgers's expected utility is higher with the capital broker. When $\alpha \leq \mathrm{K}$ the capital broker is chosen if hedgers' price impact is lower with the capital broker (part ii of proposition 3a).

A hedger chooses the discount broker if the variability of its profits is lower with the discount broker. The variability of a hedger's profits depends on the number of hedgers participating and the price impact of its trades. The result follows because, with the capital (discount) broker, the number of other hedgers participating is h-1 ( $\alpha \mathrm{h}-1)$ and the price impact is $V_{\alpha}\left|\mathrm{D}_{\mathrm{c}}\right|\left(\left|\mathrm{D}_{\mathrm{d}}\right|\right)$, respectively. The equilibrium condition also ensures that the informed trader chooses the discount broker since the standard deviation of hedger trades is higher with the latter.

We measure the execution quality received by the $\mathrm{j}$-th hedger from broker $\mathrm{i}$ as $\mathrm{E}\left(\left|\mathrm{u}_{\mathrm{j}, \mathrm{i}}\right|\right) / \mathrm{E}\left(\left|\mathrm{P}_{\mathrm{i}}\right|\right)$ $\mathrm{i}=\mathrm{c}, \mathrm{d}$. Execution is better with broker $\mathrm{i}$ if, on average, price per unit of hedgers' order flow is lower with broker $\mathrm{i}$. The quality of the informed trader's order execution by broker $\mathrm{i}$ is measured, as before, by $\mathrm{E}\left(\left|\mathrm{x}_{\mathrm{i}}\right|\right) / \mathrm{E}\left(\left|\mathrm{P}_{\mathrm{i}}\right|\right) \mathrm{i}=\mathrm{c}, \mathrm{d}$.

Corollary 3. (i) Hedgers may not choose the broker who obtains better execution. (ii) The informed trader chooses the broker who obtains better execution.

As in the noise trader model, price variance is the same with either broker. This is because the capital broker's partial offsetting of hedgers' order flow is balanced by hedgers' lower participation with the discount broker. However, when hedgers choose the discount broker, their price impact is lower but their order flow is not necessarily higher with the discount broker.

From (10) and (16), market depth depends upon hedgers' trading intensity:

$$
\frac{1}{\lambda_{d}}-\frac{1}{\lambda_{c}}=\frac{\sqrt{h \Sigma_{w}}}{\sqrt{\Sigma_{s}-\Sigma_{k}}} t\left(2 \sqrt{\alpha}\left|D_{d}\right|-\left|D_{c}\right|\right)
$$


Market depth is halved with the capital broker because she offsets half of hedgers' order flow. Depth is reduced by $\checkmark \alpha$ by the discount broker of lower hedger participation. Market depth is higher with a broker if, after adjusting for these effects, the hedging intensities is higher with the broker.

Define $H=[\alpha(h-1) /(\alpha h-1)]^{1 / 2}$ and note that $H \geq 1$. Proposition 4 relates market depth to broker choice.

Proposition 4. (i) If $\alpha \leq K$ and $\left|D_{d}\right|<\sqrt{ }\left|D_{c}\right|$, then the capital broker is chosen and market depth is higher. (ii) If $\alpha \geq 0.5$ and $\left|D_{d}\right|>\sqrt{ } H\left|D_{c}\right|$, then the discount broker is chosen and market depth is higher. (iii) If $K<\alpha<0.5$ and $\left|D_{d}\right|>\sqrt{H}\left|D_{c}\right|$, then the discount broker is chosen and but market depth may be lower.

Corollary 4. (i) If market depth is higher with the capital broker, so is the net order flow. (ii) The net order flow may be lower with the discount broker even if market depth is higher. (iii) Price informativeness is invariant to broker choice.

Figure 4, which is analogous to figure 2 for the noise trader model, illustrates proposition 4. CB (DB) denotes capital (discount) broker, md is market depth and nof is net order flow.

\begin{tabular}{lcc}
$\begin{array}{l}\mathrm{CB} \text { chosen if }\left|\mathrm{D}_{\mathrm{d}}\right| \\
<\sqrt{ } \alpha\left|\mathrm{D}_{\mathrm{c}}\right| ; \text { md and } \\
\text { nof higher }\end{array}$ & $\begin{array}{c}\mathrm{DB} \text { chosen if }\left|\mathrm{D}_{\mathrm{d}}\right| \\
\mathbf{V}\left|\mathrm{D}_{\mathrm{c}}\right| ; \text { md and nof } \\
\text { maybe lower }\end{array}$ & $\begin{array}{c}\mathrm{DB} \text { chosen if }\left|\mathrm{D}_{\mathrm{d}}\right| \\
>\sqrt{\mathrm{H}}\left|\mathrm{D}_{\mathrm{c}}\right| ; \text { md higher; } \\
\text { nof maybe lower }\end{array}$ \\
\hline 0 & $\mathrm{~K}$ & 0.5
\end{tabular}

Figure 4: Market depth, net order flow and broker choice with hedgers

When hedgers and the informed trader choose the capital broker, the hedging intensity is 
sufficiently high for market depth to be high as well. However, the discount broker may be chosen even when the hedging intensity is lower with the discount broker. As a result, market depth may be lower also. This is likely to happen when piggybacking is high enough for the discount broker to be chosen, but the number of participating hedgers is not high enough for market depth to be higher.

The difference in net order flow between the two brokers depends on the difference in market depth plus the difference in hedgers' net order flow. When depth is higher with the capital broker, the hedging intensity is high enough that hedgers' net order flow is also higher--even though the capital broker offsets half of hedger trades. However, when depth is higher with the discount broker, hedgers do not trade enough to offset the effect of lower participation. As in the noise trader model, price variance, and so price informativeness, is the same with each broker.

\section{B. Broker Choice and Market Structure}

In this section, we investigate how broker choice is related to market structure. Specifically, we focus on how broker choice depends on the following variables: the price impact of a hedger's trades $\left(\mathrm{N}_{2}\right)$, a hedger's "size"--i.e., the variance of her endowment as a proportion of aggregate endowment volatility $\left(\mathrm{N}_{3}\right)$ and the risk of trading with the informed trader (inversely related to $\mathrm{N}_{1}$ ). Equilibrium values of these variables are, in turn, functions of exogenous parameters: the number of hedgers $\mathrm{h}$, the variances $\Sigma_{\mathrm{v}}, \Sigma_{\mathrm{e}}, \Sigma_{\mathrm{w}}$, and $\Sigma_{\mathrm{k}}$ and risk-aversion R. Since traders' broker choice depends on the hedging intensities $\left|D_{c}\right|$ and $\left|D_{d}\right|$, we first discuss how these intensities are related to $\mathrm{N}_{1}, \mathrm{~N}_{2}$ and $\mathrm{N}_{3}$. The main determinant of relative hedging intensities is the change in $\left|\mathrm{D}_{\mathrm{d}}\right|$ when more hedgers participate ( $\alpha$ increases). An increase in $\alpha$ has two opposite effects on $\left|D_{d}\right|:$ it reduces the price impact of hedger trades, which increases $\left|D_{d}\right|$; and it reduces the size of a hedger, decreasing its incentive to trade. Lemma $A 2$ in the appendix relates the sign of $d\left|D_{d}\right| / d \alpha$ to $N_{i}$, 
$\mathrm{i}=1,2,3$.

When $d\left|D_{d}\right| / d \alpha$ is positive, we say there is participation externality--a hedger trades more when more hedgers participate with the discount broker. From lemma A2 in the appendix, participation externality occurs when hedgers' price impact and information risk are relatively high, and each hedger has relatively small endowment risk. For low levels of participation by hedgers, a hedger has little incentive to trade with the discount broker. As more hedgers participate, price impact is reduced and so is a hedger's size. The marginal effect of the reduction in the price impact is more, and so each hedger trades more.

When $\mathrm{d}|\operatorname{Dd}| / \mathrm{d} \alpha$ is negative, a hedger trades less when more hedgers participate with the discount broker. This happens when hedgers' price impact and information risk are low and each hedger has relatively large endowment risk. For low levels of $\alpha$, a hedger trades a lot with the discount broker. As more hedgers participate, price impact is lower, but this benefit is swamped by the lessening of each hedger's relative endowment risk, reducing a hedger's incentive to trade.

Proposition 5 relates broker choice to the exogenous parameters of the hedger model.

Proposition 5. It is more likely that the capital (discount) broker will be chosen and market depth will be higher for relatively low (high) values of $R, \Sigma_{w}, \Sigma_{v}$ and $\Sigma_{e}$; and relatively high (low) values of $h$ and $\Sigma_{k}$.

We graph, in figure 5 (when there is participation externality) and figure 6 (when there is no participation externality), simulation results showing the relationship between $\alpha$, broker choice and market depth. Figure 5a plots the hedging intensities against $\alpha$. Figure 5b plots $\alpha$ against the difference in value between the capital broker and the discount broker for these variables: market depth, hedgers' utility and the informed trader's trading intensity. A positive number indicates that 
the value is higher with the capital broker. Parameter values used in figure 5 are listed in example 1.

Example 1. $\mathrm{R}=1, \Sigma_{\mathrm{v}}=3, \Sigma_{\mathrm{s}}=3, \Sigma_{\mathrm{w}}=1, \Sigma_{\mathrm{k}}=2.5, \mathrm{~h}=10$. For these values, $\mathrm{K}=0.46, \mathrm{t}=1, \mathrm{~N}_{1}=3, \mathrm{~N}_{2}=0.45$, $\mathrm{N}_{3}=0.025, \sqrt{ } \mathrm{N}_{3} / \sqrt{ } \mathrm{N}_{1}=0.09$, and $\mathrm{N}_{2} / \mathrm{N}_{1}=0.15$. By lemma 4, equilibrium exists for $\checkmark \alpha>\mathrm{N}_{2} / \mathrm{N}_{1}$, or $\alpha>0.0225$. In addition, we require $\alpha \mathrm{h} \geq 1$, or $\alpha \geq 0.1 .\left(\mathrm{N}_{2}\right)^{2}=0.2>0.075=\mathrm{N} \mathrm{N}_{3}$, which is the condition required for participation externality, according to lemma A2.

In figure $5 \mathrm{a},\left|\mathrm{D}_{\mathrm{c}}\right|=0.86$ while $\left|\mathrm{D}_{\mathrm{d}}\right|$ is initially low and increases with $\alpha$ (there is participation externality), but never exceeds $\left|D_{c}\right|$. From figure $5 b$, hedgers' expected utility with the capital broker is always higher than that with the discount broker. Informed trading intensity is also higher with the capital broker for $\alpha<0.28$. Both hedgers and the informed trader choose the capital broker for $\alpha \in$ $(0.1,0.28)$ (in interval A) and market depth is also higher with the capital broker in this region. ${ }^{17}$ In general, it is more likely that the capital broker will be chosen and market depth will be higher for low participation rates $\alpha$. No value of $\alpha$ exists such that both hedgers and the informed trader choose the discount broker.

Figure 6a plots the hedging intensities against $\alpha$ when there is no participation externality. Figure $6 \mathrm{~b}$ plots $\alpha$ against the difference in value between the discount broker and the capital broker for these variables: market depth, hedgers' utility and the informed trader's trading intensity. A positive number indicates that the value is higher with the discount broker. Parameter values used in figure 6 are listed in example 2.

Example 2. $\mathrm{R}=1.3, \Sigma_{\mathrm{v}}=3, \Sigma_{\mathrm{s}}=4, \Sigma_{\mathrm{w}}=38, \Sigma_{\mathrm{k}}=0.01, \mathrm{~h}=9$. For these values, $\mathrm{K}=0.003, \mathrm{t}=0.75, \mathrm{~N}=4.875$, $\mathrm{N}_{2}=0.162, \mathrm{~N}_{3}=0.1621, \sqrt{ } \mathrm{N}_{3} / \mathrm{N}_{1}=0.18, \mathrm{~N}_{2} / \mathrm{N}_{1}=0.003$. According to lemma 4, equilibrium exists for

\footnotetext{
${ }^{17}$ The sufficient conditions for capital broker choice (as described in proposition 3a) are satisfied for $\alpha<0.055$.
} 
$\sqrt{ } \alpha>\sqrt{ } \mathrm{N}_{3} / \widehat{V}_{1}$, or $\alpha>0.18$. In addition, we require $\alpha>1 / \mathrm{h}-$ i.e., $\alpha>0.11 .\left(\mathrm{N}_{2}\right)^{2}=0.03<0.79=$ $\mathrm{N}_{1} \mathrm{~N}_{3}$ and $\mathrm{N}_{2}<\mathrm{N}_{3}$ : these inequalities imply no participation externality, by lemma $A 2$.

In figure $6 \mathrm{a},\left|\mathrm{D}_{\mathrm{c}}\right|=1,\left|\mathrm{D}_{\mathrm{d}}\right|$ is initially high and decreases with $\alpha$ (there is no participation externality). $\left|D_{d}\right|>\left|D_{c}\right|$ for all values of $\alpha$. Figure $6 \mathrm{~b}$ shows that hedgers' expected utility and informed trading intensity are higher with the discount broker for all values of $\alpha$. Thus, both hedgers and the informed trader choose the discount broker for $\alpha>0.11$. However, market depth is higher with the discount broker for $\alpha>0.2$ (in interval B) only. For $\alpha \in(0.11,0.2)$ (in interval A)--traders choose the discount broker but market depth is lower.

\section{Broker Choice in Large and Volatile Markets: Special Cases of the Hedger Model}

In this section, we analyze the equilibrium outcomes when some of the model parameters approach a limit. These limiting results support proposition 5 and the conclusions from our simulation exercises regarding the relationships between broker choice, market depth and the model parameters.

The first limiting result is obtained when $\mathrm{h} \rightarrow \infty$ and $\mathrm{h} \Sigma_{\mathrm{w}} \rightarrow \mathrm{C}$, where $\mathrm{C}$ is positive and finite. Implicitly, $\Sigma_{\mathrm{w}} \rightarrow 0$ as h $\rightarrow \infty$.

Proposition 6. Let $\mathrm{h} \rightarrow \infty$ in such a way that $\mathrm{h} \Sigma_{\mathrm{w}} \rightarrow \mathrm{C}, 0<\mathrm{C}<\infty$. Then:

(a) $d\left|D_{d}\right| / d \alpha>0$, and $D_{c} \geq D_{d}$.

(b) If $\sqrt{\alpha}<\mathrm{K}+\mathbf{0 . 5}\left(\mathrm{N}_{2} / \mathrm{N}_{1}\right)$, then the capital broker is chosen and market depth and the net order flow are higher.

In this "large market" case, each hedger's share of aggregate endowment risk $\left(\mathrm{N}_{3}\right)$ approaches zero as $\mathrm{h}$ approaches infinity. However, the magnitude of aggregate endowment risk $\left(\mathrm{h} \Sigma_{\mathrm{w}}\right)$ is bounded above by $\mathrm{C}$, and so hedgers' price impact is still positive. Increases in $\alpha$ lowers the price 
impact, and increases $\left|D_{d}\right|$ : there is participation externality. For $\alpha<1$, aggregate endowment risk is lower, and hedgers' price impact higher, with the discount broker. Thus, hedging intensity is higher with the capital broker. If piggybacking is not too much, all traders choose the capital broker and market depth and net order flow are higher. Consistent with proposition 5, equilibrium requires low values of $\alpha, \mathrm{R}, \Sigma_{\mathrm{v}}, \Sigma_{\mathrm{e}}$, and $\Sigma_{\mathrm{w}}$; and large values of $\mathrm{h}$.

In the second limiting case, we let each hedger's risk aversion go to infinity. We call this the "volatile market" case since, as shown below, equilibrium requires that the asset volatility be relatively high.

Proposition 7. Let $\mathbf{R} \rightarrow \infty$. Then:

(a) $\mathrm{d}\left|\mathrm{D}_{\mathrm{d}}\right| / \mathrm{d} \alpha<0$, and $\mathrm{D}_{\mathrm{c}} \leq \mathrm{D}_{\mathrm{d}}$.

(b) If $\alpha>0.5$ and $\left(\mathrm{N}_{3} / \mathrm{N}_{1}\right)>\left[\checkmark \alpha-(2 \alpha-1)^{1 / 2}\right] /\left[1-\left(2 \alpha^{2}-\alpha\right)^{1 / 2}\right]$, the discount broker is chosen, and market depth and the net order flow are higher.

When $\mathrm{R}$ is very large, then relative to her information risk, a hedger's price impact approaches zero (i.e., $\mathrm{N}_{2} / \mathrm{N}_{1} \rightarrow 0$ as $\mathrm{R} \rightarrow \infty$ ) whereas a hedger's share of endowment risk is bounded (i.e., $\mathrm{N}_{3} / \mathrm{N}_{1}$ is independent of R). As $\alpha$ increases, the main effect is to reduce hedgers' relative endowment risk, reducing the hedging intensity, and hence there is no participation externality. For $\alpha<1$, a hedger's share of endowment risk is larger with the discount broker, and so is hedging intensity. For sufficiently high $\alpha$, market depth and the net order flow are higher with the discount broker. Consistent with proposition 5, required parameter values are: small values of $\mathrm{h}$ and $\Sigma_{\mathrm{k}}$, and large values of $\alpha, \Sigma_{\mathrm{w}}$ and $\mathrm{R}$.

\section{Participation of Capital and Discount Brokers in Selected Futures Markets}


In futures markets, floor traders decide (and must announce to the exchange) at the beginning of a trading day whether to function as a dual trader or as a pure execution broker. This decision is presumably based on the floor trader's anticipation of customer preference, given the market conditions expected to prevail that day. In this section, we formulate hypotheses relating the participation of futures floor traders to market parameters, and test them using data from futures markets. The hypotheses are based on comparative static results from our hedger model, showing changes in the expected utility of hedgers and informed profits with respect to exogenous parameters.

\section{A. Comparative Static Results and Empirical Hypotheses}

We simulate the change in hedgers' expected utility and informed profits with a change in one of the exogenous variables in our hedger model. Some of the comparative static results depend on the sign of $d\left|D_{d}\right| / d \alpha$. We assume $d\left|D_{d}\right| / d \alpha>0$ since, from table 2 , the futures contracts in our samples trade in liquid markets, with a large number of trades per day. ${ }^{18}$

Table 1 summarizes the simulation results. Increases in the incentive to hedge, market size or a reduction in piggybacking benefit both brokers. For hedgers, an increase in R or $\Sigma_{\mathrm{w}}$ (which increases the incentive to hedge) reduces the price impact of their trades, directly when $\Sigma_{\mathrm{w}}$ increases, and indirectly when $\mathrm{R}$ increases, through an increase in the capacity of hedgers to bear risk. For informed traders, increases in $\mathrm{R}$ or $\Sigma_{\mathrm{w}}$ increases market depth and so informed profits. The discount broker benefits more from an increase in $\mathrm{R}$ or $\Sigma_{\mathrm{w}}$ than the capital broker because, given $\alpha<1$, the price impact is higher with the discount broker, and so the marginal reduction in the price impact is also greater.

An increase in $\mathrm{h}$ (which increases market size) reduces $\mathrm{N}_{2}$, the price impact of hedger trades

\footnotetext{
${ }^{18}$ Both lemma $A 2$ in the appendix and proposition 6 imply that $d\left|D_{d}\right| / d \alpha>0$ is more likely in markets with many hedgers.
} 
(increasing hedgers' utility) and $\mathrm{N}_{3}$, a hedger's share of aggregate endowment risk (decreasing hedgers' utility, by reducing the incentive to hedge). When $\left|D_{d}\right|$ is increasing in $\alpha$, the former effect dominates. The informed trader gains because market depth is higher with $\mathrm{h}$.

An increase in $\Sigma_{\mathrm{k}}$ reduces piggybacking and increases market depth, benefitting both hedgers and the informed trader. Increases in $\Sigma_{v}$ benefit hedgers by increasing the need to hedge, while informed traders are hurt from the decrease in market depth. Increases in $\Sigma_{\mathrm{e}}$ reduce the information precision, reducing informed profits and increasing hedgers' utility by lowering the risk of informed trading for hedgers.

Since floor trading in futures markets is a purely voluntary activity, the daily variation in the numbers of dual traders and pure brokers indicates how their level of participation changes in response to market forces. Our hypotheses, which are based on table 1, relate the numbers of dual traders and pure brokers to the number of hedgers and the asset volatility. ${ }^{19}$

Hypothesis 1. The number of dual traders and pure brokers is positively related to the number of hedgers $h$. As $h$ increases, the number of pure brokers increases more (less) than the number of dual traders if trading is primarily motivated by hedging (information).

Hypothesis 2. If trading is mainly motivated by hedging (information), the number of dual traders and pure brokers is positively (negatively) related to asset volatility $\Sigma_{v}$; and, as $\Sigma$ increases, the number of dual traders increases more (decreases less) than the number of pure brokers.

\section{B. Data and Methodology}

\footnotetext{
${ }^{19}$ These parameters are selected because it is easier to construct empirical proxies for them.
} 
We have data, received from the Commodity Futures Trading Commission (CFTC), for the following futures contracts: T-bond futures and soybean oil futures trading on the Chicago Board of Trade (CBOT); the 91 day T-bill futures and the live hog futures trading on the Chicago Mercantile Exchange (CME). Known as the Computerized Trade Reconstruction (CRT) data, it includes the following variables, dated by a 15 minute time bracket: trade quantity (number of contracts), a Customer Type Indicator (CTI) code indicating whether the trade was made for an outside customer (CTI 4) or a floor trader's personal account (CTI 1 $)^{20}$, and a code for the floor trader executing the trade. The sample period covers 30 randomly selected trading days for the 6 month time period starting August 1, 1990.

To identify dual traders and pure brokers, we first calculate a trading ratio for each floor trader for each day she is active. Specifically, define $d=$ (personal trading volume)/(personal trading volume + customer trading volume), the proportion that personal trading volume is of a floor trader's total trading volume on a day. We calculate $d$ for each floor trader for each day. For a particular day, we categorize a floor trader as a dual trader if $d$ is in the closed interval $[0.02,0.98] .{ }^{21} \mathrm{~A}$ floor trader is a pure broker if $d<0.02$.

To test our two hypotheses, we run the following regressions:

$$
\begin{aligned}
& p b_{t}=a_{0}+a_{1} V_{t}+a_{2} N_{t}+e_{1 t} \\
& d_{t}=b_{0}+b_{1} V_{t}+b_{2} N_{t}+e_{2 t}
\end{aligned}
$$

where, for day $t, d_{t}$ is the number of dual traders, $p b_{t}$ is the number of pure brokers, $V_{t}$ is the

\footnotetext{
${ }^{20}$ The other indicators are CTI 2 (trades executed for a clearing member's house account) and CTI 3 (trades for another member present on the exchange floor).

${ }^{21}$ The $2 \%$ filter is used to allow for the possibility of error trading. As Chang, Locke and Mann (1996) state, "when a broker makes a mistake in executing a customer order, the trade is placed into an error account as a trade for the broker's personal account. A value of $2 \%$ for this error seems reasonable from conversations with CFTC and exchange staff."
} 
difference between the highest and lowest price, $\mathrm{N}_{\mathrm{t}}$ is the number of customer trades and $\mathrm{e}_{1 \mathrm{t}}, \mathrm{e}_{2 \mathrm{t}}$ are error terms. $V_{t}$ is a measure of the volatility of the asset. $N_{t}$ is a proxy for $h$, the number of hedgers. By hypothesis one, $a_{2}>0$ and $b_{2}>0$. In addition, $a_{2}$ is greater (less) than $b_{2}$ if futures customers are mainly hedgers (informed traders). By hypothesis two, $a_{1}>0, b_{1}>0$ if futures customers are mainly hedgers; and $\mathrm{a}_{1}<0, \mathrm{~b}_{1}<0$ if futures customers are mainly informed traders. Further, $\left|a_{1}\right|<\left|b_{1}\right|$.

\section{Results}

Table 2 reports the daily distribution of the number of floor brokers for the four samples. Panel A reports results for dual traders. The mean number of dual traders on a day varies across contracts, ranging from 8.54 for T-bills to 151 for T-bonds, and for the same contract, across days. For live hogs futures, for example, the number of dual traders on a day varies between 9

and 23. Panel B reports the daily distribution of the number of pure brokers. The mean number of pure brokers varies between 15 for T-bills and 82 for T-bonds. For each contract, the mean number of pure brokers varies across sample days. Finally, the relative proportions of dual traders and pure brokers also vary across contracts. For example, T-bonds has almost twice as many dual traders as pure brokers, while for T-bills the opposite is true.

Table 3 presents the sample distribution of price volatility and the number of customer trades. There appears to be some correlation between these variables and the number of floor traders across contracts. T-bonds, for example, with the most number of floor brokers participating, also has the highest mean and median dollar volatility and number of customer trades. Conversely, T-bills, with the least number of participating floor brokers, also has the lowest mean and median dollar volatility and number of customer trades. Live hogs and soybean 
oil are roughly equal both in terms of participating floor brokers and volatility levels.

Table 4 presents the regression results. For T-bonds, the most active contract, volatility and the number of customer trades explain up to $70 \%$ of the daily variation in the number of floor brokers. For soybean oil, they explain $67 \%$ of the daily variation in the number of dual traders, but only $29 \%$ of pure brokers. For live hogs and T-bills, the explanatory power of our regressions is weaker.

Hypothesis one is strongly supported. The relationship between the number of dual traders and pure brokers and the number of customer trades is positive for all contracts, and significantly so in seven out of eight cases. The sole exception is T-bills for which the number of customer trades has a positive effect on the number of dual traders, but the coefficient is not significant. Also, $a_{2}>b_{2}$ for all contracts, and the difference is significant for all except live hog futures, indicating that futures trading is mainly hedging motivated.

The relationship between volatility and broker participation is weaker. While $a_{1}>0$ for three out of four contracts and $b_{1}>0$ for two out of four contracts, there is no significant coefficient. In addition, $a_{1}<b_{1}$ in absolute value for three out of four contracts---but, again, the differences are not significant for any contract.

\section{CONCLUSION}

Hedgers and an informed trader choose between a broker who takes a position in the asset (capital broker) and a broker who does not (discount broker). The capital broker exploits order flow information to mimic informed trades and offset hedgers' trades, reducing informed profits and hedgers' utility. But the capital broker has a larger capacity to execute hedgers' orders, 
increasing market depth. In equilibrium, hedgers (the informed trader) choose(s) the broker with the lowest price per unit of utility (informed order).

However, the chosen broker may not be the one with whom market depth and net order flow are higher. If the capital broker's piggybacking is high relative to its size advantage, the informed trader chooses the discount broker. But, if the discount broker is not large enough, market depth is lower as a result. Thus, the capital broker's piggybacking may create a negative externality for the market.

We relate traders' broker choice to market structure and show that the capital (discount) broker benefits customers relatively more (less) in developed securities markets---i.e, markets where there are many hedgers with low levels of risk aversion, endowment and asset volatilities. We use our model to derive hypotheses regarding the decision of futures floor traders to function as dual traders or pure execution brokers on a given day. Our regressions are able to explain up to $70 \%$ of the daily variation of the participation of floor traders in these markets.

Broker-dealers often purchase order flow through arrangements such as "payment for order flow", wherein a market maker will pay the broker a penny or two per share in exchange for the broker routing retail-order flows of specific characteristics to it. ${ }^{22}$ Both in our paper as well as in Hagerty and McDonald (1995), relative broker size is fixed, although adding more customers improves market liquidity. ${ }^{23}$ Given participation externality, however, it is not clear whether brokers will add the "optimal" (i.e., optimal for the market) number of customers. This is a subject for further research.

\footnotetext{
${ }^{22}$ See "Payment for Order Flow," (SEC, Release No. 34-33026, October 6, 1993).

${ }^{23}$ Gehrig (1993) describes a model in which brokers invest in networks to inform the market about their price offers. A larger network increases the probability that they can match buyers and sellers and effect a transaction.
} 


\section{REFERENCES}

1. Benos, Alexandros and Michel Crouhy (1995). Changes in the Structure and Dynamics of European Securities Markets. Working Paper, HEC School of Management, France.

2. Chakravarty, S. (1994). Should actively traded futures contracts come under the dual trading ban?, Journal of Futures Markets, 14, 661-684.

3. Chang, E.C., P.R. Locke, and S.E. Mann (1994). The effect of CME Rule 552 on dual traders, Journal of Futures Markets, 14, 493-510.

4. Fishman, M. J. and L.A. Longstaff (1992). Dual trading in futures markets, Journal of Finance, 47, 2, 643-671.

5. Gehrig, Thomas (1993). Natural oligopoly in intermediated markets. Discussion paper no. 1027, The Center for Mathematical Studies in Economics and Management Science, Northwestern University.

6. Grossman, Sanford J. (1989). An economic analysis of dual trading. Working paper no. 3389, Rodney L. White Center for Financial Research, the Wharton School, University of Pennsylvania.

6. Hagerty, Kathleen and Robert L. McDonald (1995). Brokerage, market fragmentation, and securities market regulation, in Lo, Andy (ed) "The Industrial Organization and Regulation of the Securities Industry," NBER Conference Report, The University of Chicago Press.

7. Kandel, Eugene and Neil D. Pearson (1995). Differential interpretation of public signals and trade in speculative markets, Journal of Political Economy, 103, 4, 831-872.

8. Kyle, A. S. (1985). Continuous auctions and insider trading, Econometrica, 53, 1315-1335.

9. Matthews, John O. (1994). "Struggle and Survival on Wall Street," Oxford University Press, 
New York, 1994.

10. Pagano, M. (1989). Trading Volume and Asset Liquidity, Quarterly Journal of Economics, $104,255-274$.

11. Pagano, M. and A. Roell (1990). Trading systems in European stock exchanges: current performance and policy options, Economic Policy, 10, 65-113.

12. Roell, A. (1990). Dual capacity trading and the quality of the market, Journal of Financial Intermediation, 1, 105-124.

13. Sarkar, Asani (1995). The regulation of dual trading: Winners, losers and market impact, Journal of Financial Intermediation, 4, 77-93.

14. Schwartz, Robert A. (1993). Reshaping the Equity Markets: A Guide for the 1990s, Business One Irwin, Illinois.

15. Spiegel, M. and Subrahmanyam, A. (1992). Informed speculation and hedging in a noncompetitive securities market, Review of Financial Studies, 5(2), 307-329. 
Page 36

Table 1

Summary of Comparative Static Results

$+(-)$ indicates a positive (negative) relation between the exogenous variable and hedgers' expected utility or informed profits.

\begin{tabular}{l|cccc}
\hline $\begin{array}{l}\text { Exogenous } \\
\text { variable }\end{array}$ & $\begin{array}{c}\text { Expected } \\
\text { utility of } \\
\text { hedgers }\end{array}$ & $\begin{array}{c}\text { Marginal utility } \\
\text { higher for }\end{array}$ & Informed profits & $\begin{array}{c}\text { Marginal profits } \\
\text { higher for }\end{array}$ \\
\hline $\begin{array}{l}\text { Risk aversion } \\
\begin{array}{l}\text { Endowment } \\
\text { volatility }\end{array}\end{array}$ & + & Discount broker & + & Discount broker \\
$\begin{array}{l}\text { Number of } \\
\text { hedgers }\end{array}$ & + & Discount broker & + & Discount broker \\
$\begin{array}{l}\text { Asset } \\
\text { volatility }\end{array}$ & + & Discount broker & + & Capital broker \\
$\begin{array}{l}\text { Information } \\
\text { precision }\end{array}$ & - & Capital broker & - & Discount broker \\
Piggybacking & & Capital broker & + & Capital broker \\
\hline
\end{tabular}


Table 2

\section{Sample Distribution of Dual Traders and Pure Brokers in Selected Futures Pits}

The table gives the daily distribution of the number of dual traders and pure brokers each day. A dual trader is a floor trader who, on a given day, trades both for its own account and for customers. A pure broker is a floor trader who trades only for customers on a given day. The sample period is 30 randomly selected trading days between August 1,1990 and January 31, 1991 for four futures contracts: live hogs and 91 day T-bills, trading on the Chicago Mercantile Exchange; Tbonds and soybean oil, trading on the Chicago Board of Trade.

\begin{tabular}{|c|c|c|c|c|}
\hline & Live hogs & Soybean oil & T-bills & T-bonds \\
\hline \multicolumn{5}{|c|}{ Panel A. Number of dual traders } \\
\hline Mean & 17.5 & 18.93 & 8.54 & 151.1 \\
\hline $\begin{array}{l}\text { Standard } \\
\text { deviation }\end{array}$ & 3.14 & 3.21 & 1.93 & 12.31 \\
\hline Minimum & 9 & 14 & 5 & 117 \\
\hline 1st Quartile & 16 & 16 & 7 & 143 \\
\hline Median & 18 & 18 & 9 & 153 \\
\hline 3rd Quartile & 19 & 21 & 10 & 161 \\
\hline Maximum & 23 & 27 & 13 & 168 \\
\hline \multicolumn{5}{|c|}{ Panel B. Number of pure brokers } \\
\hline Mean & 19 & 23 & 15 & 82 \\
\hline $\begin{array}{l}\text { Standard } \\
\text { deviation }\end{array}$ & 5 & 7 & 3 & 20 \\
\hline Minimum & 10 & 13 & 9 & 52 \\
\hline 1st Quartile & 16 & 17 & 13 & 69 \\
\hline Median & 18 & 21 & 14 & 79 \\
\hline 3rd Quartile & 22 & 27 & 16 & 93 \\
\hline Maximum & 33 & 47 & 22 & 135 \\
\hline
\end{tabular}


Page 38

\section{Table 3}

\section{Sample Distribution of Volatility and Number of Customer Trades in Selected Futures Pits}

The table gives the daily distribution of price volatility (the difference between the highest and lowest price on a day) and number of customer trades. The sample period is 30 randomly selected trading days between August 1, 1990 and January 31, 1991 for four futures contracts: live hogs and 91 day T-bills, trading on the Chicago Mercantile Exchange; T-bonds and soybean oil, trading on the Chicago Board of Trade.

\begin{tabular}{|c|c|c|c|c|}
\hline & Live hogs & $\begin{array}{l}\text { Soybean } \\
\text { oil }\end{array}$ & T-bills & T-bonds \\
\hline \multicolumn{5}{|c|}{ Panel A. Price Volatility (in dollars) } \\
\hline Mean & 376 & 330 & 207.5 & 402 \\
\hline $\begin{array}{l}\text { Standard } \\
\text { deviation }\end{array}$ & 160 & 140 & 115 & 282 \\
\hline Minimum & 132 & 170 & 75 & 60 \\
\hline 1st Quartile & 252 & 210 & 150 & 114 \\
\hline Median & 368 & 300 & 200 & 504 \\
\hline 3rd Quartile & 472 & 400 & 225 & 564 \\
\hline Maximum & 660 & 660 & 650 & 1272 \\
\hline \multicolumn{5}{|c|}{ Panel B. Number of customer trades } \\
\hline Mean & 2261 & 1165 & 812 & 7818 \\
\hline $\begin{array}{l}\text { Standard } \\
\text { deviation }\end{array}$ & 843 & 375 & 318 & 2282 \\
\hline Minimum & 523 & 579 & 423 & 3973 \\
\hline 1st Quartile & 1635 & 877 & 567 & 6142 \\
\hline Median & 2217 & 1122 & 752 & 7457 \\
\hline 3rd Quartile & 2858 & 1340 & 913 & 9389 \\
\hline Maximum & 4001 & 2133 & 1620 & 13364 \\
\hline
\end{tabular}


Table 4

Floor Trader Participation in Selected Futures Markets

The regression model for panel $\mathrm{A}$ is:

$$
p b_{t}=a_{0}+a_{1} V_{t}+a_{2} N_{t}+e_{t}
$$

where, for day $t, p b_{t}$ is the number of pure execution brokers, $V_{t}$ is the price volatility, and $N_{t}$ is the number of customer trades. In panel $\mathrm{B}$, the regression model is:

$$
d_{t}=b_{0}+b_{1} V_{t}+b_{2} N_{t}+e_{t}
$$

where $d_{t}$ is the number of dual traders on day t. The sample period is 30 randomly selected trading days between August 1, 1990 and January 31, 1991 for four contracts: hogs, T-bills, T-bonds and soybean oil. T-statistics are in parentheses.

\begin{tabular}{|c|c|c|c|c|}
\hline Parameter & Hogs & $\begin{array}{l}\text { Soybean } \\
\text { Oil }\end{array}$ & T-bills & T-bonds \\
\hline \multicolumn{5}{|c|}{ Panel A: Pure broker participation, number of customer trades and volatility } \\
\hline$a_{0}$ & $\begin{array}{l}10.03^{\star} \\
(4.655)\end{array}$ & $\begin{array}{l}4.424^{\star} \\
(1.785)\end{array}$ & $\begin{array}{c}11.64^{\star} \\
(7.582)\end{array}$ & $\begin{array}{l}26.27^{\star} \\
(3.478)\end{array}$ \\
\hline$a_{1}$ & $\begin{array}{c}2.49 \\
(0.818)\end{array}$ & $\begin{array}{c}1.25 \\
(0.151)\end{array}$ & $\begin{array}{c}-7.4 \\
(-0.55)\end{array}$ & $\begin{array}{c}3.5 \\
(0.705)\end{array}$ \\
\hline$a_{2}$ & $\begin{array}{l}0.003^{\star} \\
(1.970)\end{array}$ & $\begin{array}{c}0.015^{\star} \\
(5.182)\end{array}$ & $\begin{array}{c}0.005^{\star} \\
(2.64)\end{array}$ & $\begin{array}{l}0.007^{\star} \\
(6.394)\end{array}$ \\
\hline $\begin{array}{c}\mathrm{N} \\
\text { Adj R-square }\end{array}$ & $\begin{array}{c}29 \\
0.36\end{array}$ & $\begin{array}{c}29 \\
0.67\end{array}$ & $\begin{array}{c}29 \\
0.16\end{array}$ & $\begin{array}{c}29 \\
0.70\end{array}$ \\
\hline \multicolumn{5}{|c|}{ Panel B: Dual trader participation, number of customer trades and volatility } \\
\hline$b_{0}$ & $\begin{array}{l}13.64^{\star} \\
(8.976)\end{array}$ & $\begin{array}{c}13.14^{\star} \\
(8.03)\end{array}$ & $\begin{array}{l}6.614^{\star} \\
(6.868)\end{array}$ & $\begin{array}{c}123.09^{\star} \\
(23.22)\end{array}$ \\
\hline$b_{1}$ & $\begin{array}{c}-1.142 \\
(-0.662)\end{array}$ & $\begin{array}{c}2.76 \\
(0.508)\end{array}$ & $\begin{array}{c}9.4 \\
(1.123)\end{array}$ & $\begin{array}{c}-5.36 \\
(-1.536)\end{array}$ \\
\hline $\mathrm{p}$ value (Null: $\mathrm{a}_{1}=\mathrm{b}_{1}$ ) & 0.36 & 0.9 & 0.39 & 0.16 \\
\hline$b_{2}$ & $\begin{array}{l}0.002^{\star} \\
(2.276)\end{array}$ & $\begin{array}{l}0.004^{\star} \\
(2.156)\end{array}$ & $\begin{array}{c}0.001 \\
(1.154)\end{array}$ & $\begin{array}{l}0.004^{\star} \\
(5.453)\end{array}$ \\
\hline$p$ value (Null: $a_{2}=b_{2}$ ) & 0.80 & 0.006 & 0.19 & 0.04 \\
\hline $\mathrm{N}$ & 29 & 29 & 29 & 29 \\
\hline Adj R-square & 0.18 & 0.29 & 0.09 & 0.52 \\
\hline
\end{tabular}
Significant values are starred. $p$ values are for the null hypotheses $a_{i}=b_{i}, i=1,2$. $N$ is the number of observations. 
Page 40 